This is the peer reviewed version of the following article: Mallett, O. , Wapshott, R. and Vorley, T. (2019), How Do Regulations Affect SMEs? A Review of the Qualitative Evidence and a Research Agenda. International Journal of Management Reviews, 21: 294-316, which has been published in final form at https://doi.org/10.1111/ijmr.12191. This article may be used for non-commercial purposes in accordance with Wiley Terms and Conditions for self-archiving.

\title{
How do regulations affect SMEs? A review of the qualitative evidence and a research
} agenda

\section{Oliver Mallett, University of Stirling \\ Robert Wapshott, University of Sheffield \\ Tim Vorley, University of Sheffield}

\begin{abstract}
The effects of regulations on SMEs have garnered significant political attention internationally yet, in the academic literature, these effects remain contested. This article presents findings from a systematic literature review of qualitative evidence on the effects of regulation on SMEs. We set out the strengths of qualitative approaches in relation to other, more dominant and influential quantitative approaches. We conduct a thematic synthesis of the qualitative research to develop a conceptual framework that provides a processual, embedded understanding of the effects of regulations on SMEs. The conceptual framework highlights four key, interconnected processes: identification-interpretation; strategisation; negotiation; adaptation. This conceptual framework generates insights into dynamic and potentially indirect effects of regulations in relation to a complex array of influences external to and within the business. On the basis of these insights we propose a new research agenda.
\end{abstract}

Key words: growth; policy; regulation; small and medium-sized enterprises

\section{Introduction}

The prominence of small and medium-sized enterprises (SMEs) in economies around the world, particularly as employers and sources of potential economic growth, has captured the attention of governments and policy-makers (OECD, 2017). This is especially true where 
[Type here]

threats are perceived to the viability and prosperity of SMEs and, within this context, regulations are often framed as burdens that threaten these businesses. Consequently, questions about the effects of regulations on SMEs have become a focus for research, debate and government intervention (Kitching et al. 2015a).

Notwithstanding the influence of assertions about the burdens placed on SMEs by regulation, the relationship between lower levels of regulation and outcomes such as higher rates of SME growth remains contested and problematic (Capelleras et al. 2008; Doern, 2009). Many governments have moved from a rhetoric of deregulation towards developing 'better regulation' (e.g. the EU's Small Business Act 'think small principle', European Commission, no date) that seeks to limit negative effects on SMEs but which, to be effective, requires a robust understanding of the effects of regulation on these businesses. In reviewing the evidence, Kitching and Smallbone (2010) identify four main research areas: business perceptions; crossnational comparisons; compliance costs; and qualitative studies of compliance and adaptation. Debates have tended to be dominated by quantitative studies, especially those surveying ownermanager perceptions or making cross-country comparisons. The value of these studies is acknowledged below but it is vital to emphasise that they risk obscuring important questions concerning how SMEs engage with and adapt to regulations, which in-turn, can influence the effects of these regulations and what might constitute 'better regulation'.

As Kitching and Smallbone (2010, p. 2) argue, many studies have treated SMEs as a 'black box', relying on inferences and aggregated trends to suggest what is happening within these businesses. The complexity of the effects of regulation on SMEs, which can take dynamic, direct and indirect forms, therefore requires further consideration (Barrett et al. 2014; Kitching et al. 2015a, Kitching et al. 2015b). In this paper we address the category of qualitative studies that seek to assess this shortcoming through more detailed, in-depth research (Edwards et al. 
[Type here]

2003; Kitching and Smallbone, 2010). We analytically synthesise the insights from these studies (Walsh and Downe, 2005) to answer the research question: 'how do regulations affect SMEs?'

\section{Studying the effects of regulations on SMEs}

The OECD (no date, no page) defines regulation as the imposition of rules by government, backed by the use of penalties that are intended specifically to modify the economic behaviour of individuals and firms in the private sector'. Business regulations represent an attempt by governments and other bodies to influence or control organisations' environment and practices, for example in maintaining open markets but also in areas such as protecting employee rights. As SMEs have received increasing attention in relation to economic and social goals, so too have the effects of regulations on these businesses. It is therefore important to conceptualise SMEs and how they might differ from larger businesses.

What is an SME?

The effects of regulations on SMEs have been researched through a variety of approaches over many years (Kitching and Smallbone, 2010). These studies adopt variable definitions of SMEs, which can cause problems in comparing their findings. Here we therefore adopt the European Union's broad definition of SMEs as including micro, small and medium-sized enterprises, meaning those employing between 1 and 249 people, albeit we do not adopt criteria relating to financial data that are often not reported in the studies reviewed (European Union, 2015). This definition of an SME encompasses a broad range of businesses which differ not only in terms of size but also other factors such as their product market and forms of internal organisation that must be attended to if we are to understand how regulations affect these businesses. 
[Type here]

This heterogeneity presents one of the biggest barriers to understanding the operations of SMEs and how they manage the challenges presented by their external and internal environments. SMEs are embedded in networks and influenced by a range of institutions, including regulations, leading to variations in how they react to particular influences (Edwards et al. 2006). As we will discuss in our analysis below, these responses are shaped by both external factors, for example product markets, labour markets, social networks, and internal factors, for example resources, strategic choice, management style (Edwards et al. 2006; Gilman and Edwards, 2008). The variation and complexity of SMEs therefore has implications for understanding the effects of regulations on SMEs. Discussing the effect of regulation is too crude (Edwards et al. 2004); as Kitching et al. (2015a, p. 136) argue, 'there is no typical "small business effect" of regulation; outcomes vary over time, contingent on the agency of small businesses and their stakeholders'.

Strategically and operationally, SMEs are often considered to be dominated by the interests and goals of their owner-managers (who generally express a dislike for any measures that could interfere with their managerial prerogative (Westrip, 1986; Scott et al. 1989; Wilkinson, 1999). Owner-manager prerogative refers to the extent to which the owner-manager can assert their will on the business and how it operates. Where this is strong, the owner-manager is likely able to influence how a business responds to competing demands, for example by avoiding them or otherwise accommodating them.

Such prerogative, however, is not without constraints. 'Resource poverty' (Welsh and White, 1981, p. 18) describes how SMEs might lack important resources that would enable them to cope with the consequences of internal errors and external shocks (Gill, 1985; Cassell et al. 2002). In this way, SMEs might have limited scope for adapting operations or seeing out challenging circumstances. Further, prerogative is unlikely to exist uncontested as the 
[Type here]

business's negotiated order (Ram, 1994) might require competing interests of stakeholders to be accommodated (Holliday, 1995; Moule, 1998). These relations and negotiations often occur in environments of high degrees of informality, relative to larger businesses (Ram et al. 2001), where policies might in some senses exist but not be implemented (Ram, 2000; Hoque and Noon, 2004) and allow flexibility in the arrangement and completion of tasks, although also proving resistant to the increases in formality (Mallett and Wapshott, 2014; Marlow et al. 2010) that are often associated with regulations.

This literature on how SMEs operate signals implications for how regulations might be engaged with and adapted to. Practices and outcomes are not determined simply by the external regulatory pressures encountered by a business, there is scope for owner-manager (and employee) agency and other influences in shaping practices and outcomes. Before we review the qualitative studies exploring how SMEs are affected by regulation we will provide an overview of the three other approaches identified by Kitching and Smallbone (2010) that relate to studies of: owner-manager perceptions; cross-national variation; and compliance costs. We take each of these in turn, outlining their contribution and, crucially, their potential weaknesses that necessitate the present article's focus on qualitative studies.

\section{Owner-manager perception surveys}

A sense of how regulations can affect SMEs has been gathered through surveys of ownermanager perceptions of these effects. For example, governments regularly survey business owners about a range of issues, including regulations, asking them to indicate the degree to which these issues constrain or enable outcomes such as business growth. This is important because how owner-managers understand regulations and interpret their significance can influence business decisions (Moynihan et al. 2012). De Jong and van Witteloostuijn (2014), for example, suggest the challenges of owner-manager perceptions of barriers but also of 
[Type here]

regulatory change which, in and of itself, can create burdens for businesses and challenges to growth due to the costs involved in maintaining up-to-date knowledge and understanding (see also, Grunhagen and Berg, 2011). Provided that research instruments are able to access ownermanager perceptions accurately, understanding how they view the impacts of regulation has the potential to provide valuable information (Kitching et al. 2015a).

However, reliance on surveys of owner-manager perceptions brings its own problems. Evidence indicates that SME owner-managers possess varying degrees of knowledge and understanding on the details of regulations (e.g. Clifton and Tatton-Brown, 1979; Marlow, 2003; Hart and Blackburn, 2005). Moreover, entrepreneurs have been found to demonstrate a tendency to internalise causes of success while externalising causes of failure or underperformance (Rogoff et al. 2004). Perhaps as a consequence, these types of survey can produce very mixed results where regulation is often not seen as a core concern (see e.g. IFF Research, 2012; SBRT, no date).

Owner-manager perceptions of regulations and their effects can influence practices but ought not to be treated as signalling a direct relationship between regulations, business responses and outcomes. The views captured might relate more to a general 'world view' (Edwards et al. 2003) of how owner-managers feel about regulations (or, in some surveys the pejoratively labelled 'red tape', Bozeman, 1993) rather than a comment on the effects of specific regulations in their businesses. It is therefore a significant weakness that studies of owner-manager perceptions tend to lack understanding of the impacts of these perceptions, how they manifest in practice or how robust they are. Overcoming this limitation requires approaches such as indepth interviews that are capable of engaging with practices in use and of probing ownermanager perceptions more deeply.

\section{Cross-country comparison studies}


[Type here]

Cross-country comparisons seek to identify the effects of particular regulations or regulatory regimes on enterprise and SME activity. Drawing on large, macroeconomic data sets to analyse how levels of regulation can influence business activity, these studies provide insight into how regulations can affect levels and types of activity in an economy. This can be seen, for example in the work of Simeon Djankov. Djankov et al. (2002) compared regulations relating to business entry across 85 countries, arguing that the costs of regulation present a burden on entrepreneurs and reduce the number of start-ups and the rate of business growth. Such evidence supports the creation of a low-regulation economy, principally through deregulation, which continues to be promoted by influential organisations such as the European Union (Van Stel et al. 2007) and the World Bank (Djankov, 2009).

However, this type of data sheds only limited light on enterprise-level experiences of how regulation affects SME growth. Djankov et al. (2002), for example, study what they term a 'standardized' business which is 'a domestically owned limited liability company' operating in general industry in the country's largest city with 5-50 employees and 'turnover of up to 10 times its start-up capital' (p. 7). Such studies therefore often draw inferences from official data aggregating the experiences of relatively large, legally registered SMEs, over-generalising and obscuring some of the variation within this broad category of businesses.

The influential 'Djankov view' has been contrasted, by Capelleras et al. (2008), with the 'Baumol view', reflecting the work of William J. Baumol (e.g. Baumol, 1990), which argues that regulations provide a set of rules and routines that influence the form but not the quantity of start-ups and enterprise growth. Capelleras et al. (2008) provide compelling support for this argument through an empirical comparison between relatively low-regulation England and high-regulation Spain. They found that the latter might encourage more businesses to remain unregistered but does not significantly affect the overall quantity of business start-up or 
[Type here]

employment growth. Van Stel et al.'s (2007) large scale study also found that entry regulation does not affect rates of entrepreneurship but that it might affect the distribution of businesses activity between the formal and informal economy. They also suggest that labour market regulations may have greater influence than entry regulations. What is apparent from Capelleras et al. and Van Stel et al.'s analysis is that there is no simple relationship between regulation and start-up or SME activity.

In cross-country comparisons, with a focus on measuring the effects of regulations on SMEs at aggregate levels, there is no engagement with the ways in which regulations are responded to within the businesses. Excluding such consideration of how organisations might respond to regulations risks framing these businesses, or more specifically their owners and other stakeholders, as passive in the face of regulations that are simply accepted and the effects of regulations on businesses as somewhat undifferentiated. Kitching and Smallbone (2010, p. 13) argue that these types of study are 'suggestive of a causal connection but, by neglecting the views of the agents deciding whether or not to start a business, they ignore the very important, and necessary, subjective element in the entry process'. In contrast, engaging with business operations at an enterprise-level enables insights to be informed by the heterogeneity of SMEs and examination of how variations in outcomes might arise.

\section{Compliance costs studies}

The third set of studies seeks to quantify the costs of compliance on businesses, for example in terms of the costs associated with understanding and adapting to new rules and obligations (Smallbone and Welter, 2001) and often focusing on the compliance costs associated with taxation (Chittenden et al. 2003). However, such studies also assess less direct effects such as affinity costs, where regulatory compliance requires accompanying changes (Edwards et al. 2004), and psychological costs such as stress (Chittenden et al. 2002), often without the 
[Type here]

necessary resources or expertise of in-house HR professionals to readily accommodate changes (Harris, 2000; Hart and Blackburn, 2005).

These studies utilise a range of methods, including econometrics and evaluative surveys, where accurate measurement is crucial to quantifying the degree of costs and benefits (Chittenden et al. 2009). Hahn (1998), for example, discusses the increasing use of economic analyses in debates about regulation, suggesting that very few new regulations would pass a cost-benefit assessment. A detailed report by Chittenden et al. (2002) reviews this evidence and identifies four main approaches to researching compliance costs: aggregations of previous studies to estimate the impact of compliance costs on the economy; aggregations of government impact assessments for an individual agency; surveys of businesses about the compliance costs they have incurred; and surveys of businesses about the impact of a particular area of compliance. For present purposes, a key finding from such studies is the regressive nature of the costs, that they affect SMEs, especially smaller businesses, disproportionately (Chittenden et al. 2002). Such arguments have been influential, for example in shaping impact assessments of new regulations and policies that seek to offset the burdens of new regulations by the removal of existing costs (e.g. HM Government, 2011).

However, variations in the effects of regulation are more complicated than a simple effect of business size (see e.g. Carter et al. 2009) and this suggests the need for deeper understanding. As we will discuss, the introduction of the National Minimum Wage (NMW) in the UK was expected to cause significant compliance costs. However, its impact was not as simple as compliance cost studies might suggest but resulted in a broad range of effects determined by a range of factors within and external to businesses (Heyes and Gray, 2001; Arrowsmith et al. 2003). Kitching and Smallbone (2010, p. 14) argue that 'Quantifying costs and benefits is [...] extremely difficult, particularly where these are intangible and/or likely to accrue over a long 
[Type here]

period of time.' There are significant difficulties in attempting to quantify (and especially to monetise) all costs and benefits (Hahn, 1998; Chittenden et al. 2009). Robust assessment requires a more rounded, contextualised view of organisations to appreciate the varied significance of regulations to different businesses along with the indirect and dynamic effects of regulations.

Debates about the effects of regulations on SMEs have been dominated by evidence drawn from surveys of owner-manager perceptions, cross-country comparisons and compliance costs. However, what is lacking from this influential evidence base is a detailed, in-depth understanding of how regulations affect SMEs. This is particularly important if we are to understand the dynamic and often indirect nature of regulations' effects. One way of complementing the relative strengths of these studies and addressing certain of their weaknesses is through in-depth, qualitative analysis of the effects of regulations on SMEs. It is therefore this type of qualitative research that we will review to answer our research question, 'how do regulations affect SMEs?'

\section{Method}

A literature review is particularly well-suited to this type of research question because it is more extensive in terms of the variety of businesses, contexts and regulations than typically feature in a single study. This variety helps to identify a richer, more in-depth range of perspectives on how regulations affect SMEs, generating insights into processes and context that are missing from the more dominant studies derived from quantitative forms of research.

We followed the systematic literature review procedures described by Tranfield et al. (2003) which incorporate stages of planning, conducting and reporting the review. Starting with our research objective, to answer the question 'how do regulations affect SMEs?', search strings were constructed around combinations of terms relating to regulation and SMEs. A variety of 
[Type here]

terms was used, for example, 'regulation' was extended to include 'statute' and 'legislation' and this was repeated for 'SME' to incorporate terms such as 'small business'. Search terms were extended within the search engines by applying * to the stem of words (i.e. 'regulat*' to capture 'regulations', 'regulatory' and so on).

The review was conducted using Scopus and Web of Science databases. In common with Mabey (2013) and Wilson et al. (2017), we restricted our searches to articles contained within journals included in the Chartered Association of Business Schools' Academic Journal Guide (2015). From the journal list, searches were concentrated in journals from the most relevant categories for this study: Entrepreneurship \& Small Business Management; General Management, Ethics \& Social Responsibility; and Human Resource Management \& Employment Studies in outlets rated as three-star and above (after Wilson et al. 2017). These journals, as a minimum, are considered to:

publish original and well executed research papers and are highly regarded. These journals typically have good submission rates and are very selective in what they publish. Papers are heavily refereed. (ABS, 2015, p. 7)

We focused on these journals because the ABS list is an influential guide and more impactful and revealing findings are likely to be submitted to the more respected, high-status journals. However, we acknowledge the criticisms associated with journal lists, for instance the narrowing effects they can produce in terms of subjects and approaches (Willmott, 2011; Mingers and Willmott, 2013; Tourish and Willmott, 2015). Nevertheless, as one indicator of quality it provides a valuable focus for the purposes of our review (Baldacchino et al. 2015; Adams et al. 2016). We also extended the scope of our review by utilising a narrative check (discussed below) to address these limitations. 
[Type here]

The initial searches returned 422 articles. Search results were checked for duplication between databases and the abstract for each article was reviewed to check that articles used qualitative research techniques to study the effects of regulations (in general or specific forms of regulation) on SMEs (or a subset of businesses within this broad category). This stage excluded a large number of articles that were clearly not qualitative or used our search terms in ways not appropriate for this review (for example, studying psychological self-regulation).

The remaining 85 articles were sorted into categories on the basis of how relevant the abstract was considered to our focus. Where an article appeared to be directly relevant to our study it was reviewed in detail; abstracts indicating that an article might be partly relevant were followed up with an initial, focused reading of the article to confirm its inclusion or exclusion on the basis of relevance; and, where an article's abstract indicated the article was not relevant to our study (but this was not sufficiently clear for the article to have been sifted out), this was double-checked and the article was either discarded or moved to one of the other two categories.

Given our focus on in-depth, qualitative studies, we excluded research where the regulation aspect was incidental or peripheral to the main focus of the study or its findings, for example where regulation was an element of a broader investigation such as CSR activities, but the findings presented did not explore its effects in sufficient detail to warrant inclusion in the review. Examples of peripheral articles are those where property rights were identified as an important part of a stable operating environment (or in terms of perceptions of international markets) but there was no detailed discussion of how regulations affected SMEs beyond securing this stability. This also extended to mixed methods studies where the qualitative element lacked detailed reporting in the article such that the research, as reported, was essentially quantitative in nature and not suitable for our purposes. We did include mixed 
[Type here]

methods studies, for example Anyadike-Danes et al. (2008), where the findings from the qualitative aspect of the study are discussed in detail. This produced a list of 18 articles.

In addition to the systematic element of our search we incorporated a narrative check to enhance the rigour of our searches (following Thorpe et al. 2005). Articles known to be relevant were included if absent from the search results and this was supported by following-up any relevant studies, including grey literature, cited in the articles identified in the systematic review. Adams et al. (2016) define grey literature as 'the diverse and heterogeneous body of material available outside, and not subject to, traditional academic peer-review processes' ( $\mathrm{p}$. 2). Here we take a restricted range of grey literature in line with our research aims of in-depth, qualitative analysis of how regulations affect SMEs. These checks identified an additional 18 studies, including five government-commissioned research papers, all of which were produced by or in collaboration with respected academics in the field.

Table 1 presents an overview of the 36 studies included in the review with a brief summary of their research focus and context. Here 'owner-manager' is used in a general way to refer to owners, senior managers and decision-makers within the businesses in order to encompass variation across the studies, many of which conducted interviews with the key decision-maker in the business. We use the term owner-manager as referring to this senior figure throughout the article, although we acknowledge that questions of ownership and management can vary significantly.

We conducted a qualitative synthesis of the review material to address our research question. This approach is more inclusive than, for example, meta-analyses and 'capable of integrating different forms of evidence generated from different methods such as action research, case studies, in-depth interviewing and observation studies' (Denyer and Tranfield, 2006, p. 222). We adopted a 'thematic synthesis' approach to our analysis (Thomas and Harden, 2008) 
[Type here]

because the qualitative studies reviewed are not rigorously comparable and many of them place an emphasis on context. We therefore followed Tranfield et al. (2003, p. 217) in the development of our 'data extraction form' (in our case in a shared spreadsheet) which recorded not only bibliographical, methodological and empirical details but also those pertaining to context. This information was then utilised when analysing and synthesising the findings to retain the context-sensitive nature of many of the studies reviewed rather than to risk homogenising these contexts. This information is invaluable when performing literature reviews in management studies, particularly in relation to the heterogeneous category of SMEs, where the research reviewed may be conducted on the basis of different premises or with a different focus (Tranfield et al. 2003).

We sought not to describe the studies reviewed but to identify analytical themes as they responded to our research question (Harden and Thomas, 2005). Our analysis therefore moved from identifying first order concepts within the articles, reflecting the meaning in the texts analysed, to second order analytical themes, reflecting our interpretations as part of the analytical process and then to overarching theoretical, aggregate dimensions (Gioia et al. 2013; see Table 2). The analytical themes and then the aggregate dimensions were identified through an iterative analytical process, including 'thinking about the data theoretically, not just methodologically' (Gioia et al. 2013, p. 21), a level of abstraction that allowed us to generate theoretical insights into the research question that are rigorously built upon the empirical studies we were synthesising through our analysis (Harden and Thomas, 2005). This approach allows us to acknowledge the importance of preserving the meaning and context in the original article but also to pursue greater understanding of our research question through an interpretive synthesis of the material reviewed (Walsh and Downe, 2005). 


\begin{tabular}{|c|c|c|c|}
\hline Authors & Regulation focus & Research design & Empirical focus \\
\hline Alvarez et al. 2015 & General & $\begin{array}{l}\text { In-depth historical case study based on a variety of sources including } \\
\text { interviews and interviews with employees conducted by firm family } \\
\text { members, secondary sources }\end{array}$ & 1 entrepreneur (Wakefield Superfields) (USA) \\
\hline $\begin{array}{l}\text { Anyadike-Danes et } \\
\text { al. } 2008\end{array}$ & General & $\begin{array}{l}\text { Semi-structured interviews with owner-managers [also a large scale } \\
\text { phone survey not included here] }\end{array}$ & $\begin{array}{l}124 \text { SME owners (or managers) incorporating businesses with a range } \\
\text { of size and sector characteristics (UK) }\end{array}$ \\
\hline $\begin{array}{l}\text { Arrowsmith et al. } \\
2003\end{array}$ & $\begin{array}{l}\text { National minimum } \\
\text { wage }\end{array}$ & $\begin{array}{l}\text { Semi-structured interviews of owner-managers and employees prior to } \\
\text { the introduction of NMW, with repeat management interviews a year } \\
\text { later }\end{array}$ & $\begin{array}{l}55 \text { SMEs ( } 10-50 \text { employees) in clothing manufacture (27), and hotels } \\
\text { and catering (28), repeat interviews - }-5 \text { firms (refusal/ceased training) } \\
\text { (UK) }\end{array}$ \\
\hline $\begin{array}{l}\text { Atkinson et al. } \\
2016\end{array}$ & General & Semi structured interviews with owner-managers and employees & 3 medium-sized firms (differing sectors), 41 interviews in total (UK) \\
\hline Bhatt et al. 2017 & $\begin{array}{l}\text { General (in } \\
\text { relation to social } \\
\text { enterprises) }\end{array}$ & $\begin{array}{l}\text { Q-Methodology based on interviews with a variety of stakeholders and } \\
\text { social entrepreneurs }\end{array}$ & $\begin{array}{l}321 \text { interviews: } 88 \text { in Beijing; } 71 \text { in Inner Mongolia; } 85 \text { in Shanghai; and } \\
77 \text { in Sichuan (China) }\end{array}$ \\
\hline $\begin{array}{l}\text { Bischoff and Wood } \\
2013\end{array}$ & $\begin{array}{l}\text { Employment (but } \\
\text { focus on } \\
\text { bargaining) }\end{array}$ & In-depth interviews & $\begin{array}{l}11 \text { owner-managers South African manufacturing SMEs and a cross } \\
\text { section of stakeholders in the manufacturing sector, government } \\
\text { officials, labour lawyers, consultants, Bargaining Council inspectors } \\
\text { and trade union officials. (South Africa) }\end{array}$ \\
\hline Druker et al. 2005 & $\begin{array}{l}\text { National minimum } \\
\text { wage }\end{array}$ & In-depth interviews & 48 hairdressing owner-managers in all regions of the UK \\
\hline $\begin{array}{l}\text { Edwards et al. } \\
2003\end{array}$ & Employment & $\begin{array}{l}101 \text { interviews, employee handbooks were consulted and tours of } \\
\text { manufacturing sites. }\end{array}$ & $\begin{array}{l}16 \text { cases systematically chosen from three sectors - care homes, } \\
\text { consultancy and manufacturing (UK) }\end{array}$ \\
\hline $\begin{array}{l}\text { Edwards et al. } \\
2004\end{array}$ & Employment & $\begin{array}{l}101 \text { interviews, employee handbooks were consulted and tours of } \\
\text { manufacturing sites. }\end{array}$ & $\begin{array}{l}16 \text { cases systematically chosen from three sectors - care homes, } \\
\text { consultancy and manufacturing (UK) }\end{array}$ \\
\hline Gilman et al. 2002 & $\begin{array}{l}\text { National minimum } \\
\text { wage }\end{array}$ & $\begin{array}{l}\text { Semi-structured interviews with owner-manager and with one } \\
\text { employee (all but two firms) }\end{array}$ & $\begin{array}{l}81 \text { small firms ( } 10-50 \text { employees but some exceptions) from } 3 \text { sectors: } \\
\text { clothing, print and hotel/catering (UK) }\end{array}$ \\
\hline $\begin{array}{l}\text { Grimshaw and } \\
\text { Carroll } 2006\end{array}$ & $\begin{array}{l}\text { National minimum } \\
\text { wage }\end{array}$ & $\begin{array}{l}\text { Semi-structured interviews with owner-managers (interviewed } 19 \\
\text { employees but not included here) }\end{array}$ & 36 SMEs in six low-paying sectors (1-100+ employees) (UK) \\
\hline Harris 2002 & Employment & $\begin{array}{l}\text { Semi-structured interviews with owner-managers and employee } \\
\text { representatives in two firms }\end{array}$ & $\begin{array}{l}6 \text { case study firms. Initial strategy for } 25-100 \text { employees (sampled for } \\
\text { similar size not sector) but included two smaller firms for variation (UK) }\end{array}$ \\
\hline Harris et al. 2012 & Litigation & Interviews with owner-managers, four focus groups & $\begin{array}{l}6 \text { case study small firms ( } 25-100 \text { employees, manufacturing and } \\
\text { services) and a wider sample of small firms for focus groups ( } 2 \text { owner- } \\
\text { managers, } 2 \text { with employers and stakeholders such as FSB) (UK) }\end{array}$ \\
\hline Hasle et al. 2012 & Health and safety & $\begin{array}{l}\text { Qualitative interviews with owner-managers (or similar, plus employee } \\
\text { reps in some interviews in metal industry) }\end{array}$ & 23 SMEs in metal and construction industries (Denmark) \\
\hline $\begin{array}{l}\text { Heyes and Gray } \\
2001\end{array}$ & $\begin{array}{l}\text { National minimum } \\
\text { wage }\end{array}$ & $\begin{array}{l}\text { Interviews with owner-managers as follow up to survey (we focus on } \\
\text { interviews) }\end{array}$ & 8 SMEs W Yorks textiles and clothing industry (UK) \\
\hline $\begin{array}{l}\text { Heyes and Gray } \\
2004\end{array}$ & $\begin{array}{l}\text { National minimum } \\
\text { wage }\end{array}$ & $\begin{array}{l}\text { Semi-structured interviews with owner-managers as follow up to survey } \\
\text { (we focus on interviews) }\end{array}$ & $\begin{array}{l}12 \mathrm{SMEs} \text { ( } 2-41 \text { employees) in four industries: hotels, restaurants, motor } \\
\text { vehicle maintenance and residential care homes (UK) }\end{array}$ \\
\hline
\end{tabular}




\begin{tabular}{|c|c|c|c|}
\hline Hirschsohn 2008 & $\begin{array}{l}\text { Skills and } \\
\text { development } \\
\text { legislation }\end{array}$ & Interviews with owner-managers & $\begin{array}{l}13 \text { case studies conducted in greater Cape Town (part of wider study) } \\
\text { sampled in terms of approach to training, including manufacturing, } \\
\text { food/beverage and professional services (South Africa) }\end{array}$ \\
\hline Jones et al. 2006 & Immigration & $\begin{array}{l}\text { Qualitative interviews with owner-managers and one immigrant } \\
\text { employee per firm }\end{array}$ & $\begin{array}{l}20 \text { West Midland firms from clothing (10) and restaurant (10) sectors } \\
\text { (UK) }\end{array}$ \\
\hline Jordan et al. 2013 & Employment & $\begin{array}{l}\text { In-depth interviews with micro and small business owner-managers, a } \\
\text { case study approach for larger businesses, interviewing an individual } \\
\text { with a designated HR function and one or two line managers. }\end{array}$ & 40 firms from $<10$ employees to $1000+(\mathrm{UK})$ \\
\hline Kistruck et al. 2015 & $\begin{array}{l}\text { Registration } \\
\text { (entering formal } \\
\text { economy) }\end{array}$ & $\begin{array}{l}\text { Multi-method approach, including preliminary interviews with } 52 \\
\text { entrepreneurs followed by a survey of } 247 \text { entrepreneurs (formal and } \\
\text { informal) to test hypotheses drawn from interviews }\end{array}$ & 299 entrepreneurs within Guatemala City (Guatemala) \\
\hline Kitching 2016 & General & Semi structured interviews & $\begin{array}{l}13 \text { micro-firms (up to } 9 \text { employees) and } 7 \text { small firms (10-49 } \\
\text { employees) in the manufacturing, construction, and personal and } \\
\text { business services sectors (UK) }\end{array}$ \\
\hline $\begin{array}{l}\text { Kitching et al. } \\
2015 \mathrm{a}\end{array}$ & General & $\begin{array}{l}\text { Adopts a critical realist perspective, face-to-face interv } \\
\text { semi-structured interview topic guide }\end{array}$ & $\begin{array}{l}124 \text { small and medium-sized business owners/managers from } \\
\text { independent businesses employing } 1-249 \text { people in a variety of sectors } \\
\text { (UK) }\end{array}$ \\
\hline $\begin{array}{l}\text { Kitching et al. } \\
2015 b\end{array}$ & Accounting & Surveys and interviews & $\begin{array}{l}\text { Small company preparers/users of abbreviated accounts (149 surveys, } \\
12 \text { interviews), Accounts users and intermediary bodies }(0 / 18), \\
\text { Accountants in practice }(255 / 10) \text {, Organisational accountants (159/10) } \\
\text { (UK) }\end{array}$ \\
\hline Leung 2003 & Immigration & $\begin{array}{l}\text { Interviews with Chinese restauranteurs and reading community } \\
\text { publications }\end{array}$ & $\begin{array}{l}22 \text { informants ( } 18 \text { male, four female) were interviewed, who are of } \\
\text { diverse geographical background (Germany) }\end{array}$ \\
\hline $\begin{array}{l}\text { Lynch-Wood and } \\
\text { Williamson } 2014\end{array}$ & Civic & Interviews & 110 manufacturing SMEs (across several related studies) (UK) \\
\hline Ojo et al. 2013 & Informal economy & Observation and inte & $\begin{array}{l}\text { Nigerian entrepreneurs in London, including } 15 \text { formal sector, } 10 \\
\text { informal sector and } 5 \text { self-acclaimed 'business persons' representing } \\
\text { criminal activities (UK) }\end{array}$ \\
\hline Ram et al. 2001 & $\begin{array}{l}\text { National minimum } \\
\text { wage }\end{array}$ & $\begin{array}{l}\text { Survey but mainly focus on } 5 \text { case studies to explore patterns identified } \\
\text { from survey }\end{array}$ & $\begin{array}{l}81 \text { small firms in printing, clothing and hotels and catering interviewed } \\
\text { face-to-face before and after changes, case studies a food } \\
\text { manufacturer, } 2 \text { restaurants and } 2 \text { garment manufacturers (UK) }\end{array}$ \\
\hline Ram et al. 2007 & $\begin{array}{l}\text { National minimum } \\
\text { wage }\end{array}$ & $\begin{array}{l}\text { Interviews with employers and employees conducted by 'community } \\
\text { insiders' for ethnic minority businesses }\end{array}$ & $\begin{array}{l}17 \text { case studies was conducted, nine from clothing and eight from } \\
\text { catering (UK) }\end{array}$ \\
\hline $\begin{array}{l}\text { Revell and } \\
\text { Blackburn } 2004\end{array}$ & Environmental & Face-to-face interviews & $\begin{array}{l}\text { Twelve 'key informants' drawn from industry and government, and } 40 \\
\text { SME owner-managers in the construction and restaurant industries in } \\
\text { London and Leeds (UK) }\end{array}$ \\
\hline Scott et al. 1989 & General & $\begin{array}{l}\text { Telephone survey and case studies developed from visiting a } \\
\text { subsample three times over one year. (Part of a broader study of IR in } \\
\text { small firms) }\end{array}$ & $\begin{array}{l}\text { Survey } 397 \text { SFs }(90 \%<50 \text { employees) in } 4 \text { locations in England and } \\
\text { Scotland (and some large firms for comparison), subsample of } 30 \text { firms }\end{array}$ \\
\hline
\end{tabular}




\section{[Type here]}

\begin{tabular}{|c|c|c|c|}
\hline $\begin{array}{l}\text { Terjesen and Elam } \\
2009\end{array}$ & Internationalisation & $\begin{array}{l}\text { Case studies from interviews, with particular attention to the individual-, } \\
\text { institutional-, and meso-level factors }\end{array}$ & 4 transnational entrepreneurs \\
\hline Undy et al. 2002 & $\begin{array}{l}\text { National minimum } \\
\text { wage }\end{array}$ & Interviews and related documents & 42 SME owner-managers in Northern Ireland and East Midlands (UK) \\
\hline Vickers et al. 2003 & Health and safety & $\begin{array}{l}\text { Telephone survey of } 1000+\text { small businesses and face-to-face } \\
\text { interviews with managers, employees, intermediaries and health and } \\
\text { safety inspectors }\end{array}$ & $\begin{array}{l}\text { Managers (73), employees (21) [we exclude support findings and } \\
\text { survey] (UK) }\end{array}$ \\
\hline Vickers et al. 2005 & Health and safety & $\begin{array}{l}\text { Telephone survey of } 1000+\text { small businesses and face-to-face } \\
\text { interviews with managers, employees, intermediaries and health and } \\
\text { safety inspectors }\end{array}$ & $\begin{array}{l}\text { Managers (73), employees (21) [we exclude support findings and } \\
\text { survey] (UK) }\end{array}$ \\
\hline $\begin{array}{l}\text { Wilkinson et al. } \\
2007\end{array}$ & $\begin{array}{l}\text { Information and } \\
\text { Consultation of } \\
\text { Employees (ICE) } \\
\text { Regulations }\end{array}$ & Case studies of SMEs, interviews and access to employee survey & $\begin{array}{l}41 \text { respondents across } 12 \text { case study organisations. focus on } 4 \text { that } \\
\text { claimed to have introduced employee involvement, average six } \\
\text { employees per company (all } 4 \text { long established) (UK) }\end{array}$ \\
\hline $\begin{array}{l}\text { Williamson et al. } \\
2006\end{array}$ & Environmental & Semi structured interviews & $\begin{array}{l}31 \text { manufacturing SME owner/managers of SMEs located in the West } \\
\text { Midlands (UK) }\end{array}$ \\
\hline
\end{tabular}

Table 1: Studies included in the literature review 


\section{1st order concepts}

Many owner-managers unsure on specifics of regulation (Anyadike-Danes et al. 2008; Edwards et al. 2003; Revell and Blackburn, 2004; Vickers et al. 2003, 2005)

Monitoring of environment (Williamson et al. 2006)

2nd order themes

\section{Aggregate}

dimensions

Awareness of regulations

Business support (e.g. solicitors) (Harris et al. 2012; Jordan et al. 2013; Kitching, 2016; Kitching et al. 2015b; Vickers et al. 2003)

Regulators (Hirschsohn, 2008; Revell and Blackburn, 2004; Vickers et al. 2003)

Sector norms, informal networks (Hasle et al. 2012; Kitching, 2016)

Employee understanding (e.g. through internal documentation, trade unions) (Atkinson et al. 2016; Harris, 2002)

Need for clarity and stability around regulation (Bhatt et al. 2017)

Desire to protect flexibility/informality (Edwards et al. 2003; Harris, 2002; Harris et al. 2012; Jordan et al. 2013)

Compliance costs (Edwards et al. 2003)

Views not necessarily informed by particular experience (Arrowsmith et al. 2003; Edwards et al. 2003; Harris et al. 2012; Jordan et al. 2013)

Positive view of regulation (Grimshaw and Carroll, 2006)

Perceived benefits in compliance in relation to business objectives (Anyadike-Danes et al. 2008; Kistruck et al. 2015)

Decision-maker values (Grimshaw and Carroll, 2006; Jordan et al. 2013; Ram et al. 2007)

Norms and other external influences on attitudes (Heyes and Gray, 2004; Lynch-Wood and Williamson, 2014; Ojo et al. 2013; Wilkinson et al. 2007)

Innovative responses to regulation (Harris, 2002; Druker et al. 2005; Grimshaw and Carroll, 2006; Ram et al. 2001)

Proactive approach to regulation (Harris, 2002; Druker et al. 2005; Leung, 2003; Terjesen and Elam, 2009; Williamson et al. 2006)

Ensure compliance (Arrowsmith et al. 2003; Harris, 2002; Druker et al. 2005; Jordan et al. 2013; Lynch-Wood and Williamson 2014; Scott et al. 1989; Williamson et al. 2006)

Critical incidents (Arrowsmith et al. 2003; Kitching, 2016)

Resource constraints on strategies (Anyadike-Danes et al. 2008; Kitching, 2015a; Lynch-Wood and Williamson, 2014)

Choose not to grow to avoid regulations (Bischoff and Wood, 2013)

Change practices to avoid regulations (Jordan et al. 2013)

Informal economy to avoid regulations (Ojo et al. 2013)
Sources of

information relevant to

regulation

\section{Perceived threats}

from regulation

General perception of regulation

Perceived benefits

Orientation towards

Proactive stances towards regulation

Respond by compliance

Resource availability

Avoidance of

regulations

Evasion of regulations
IdentificationInterpretation

Strategisation matters of regulation 


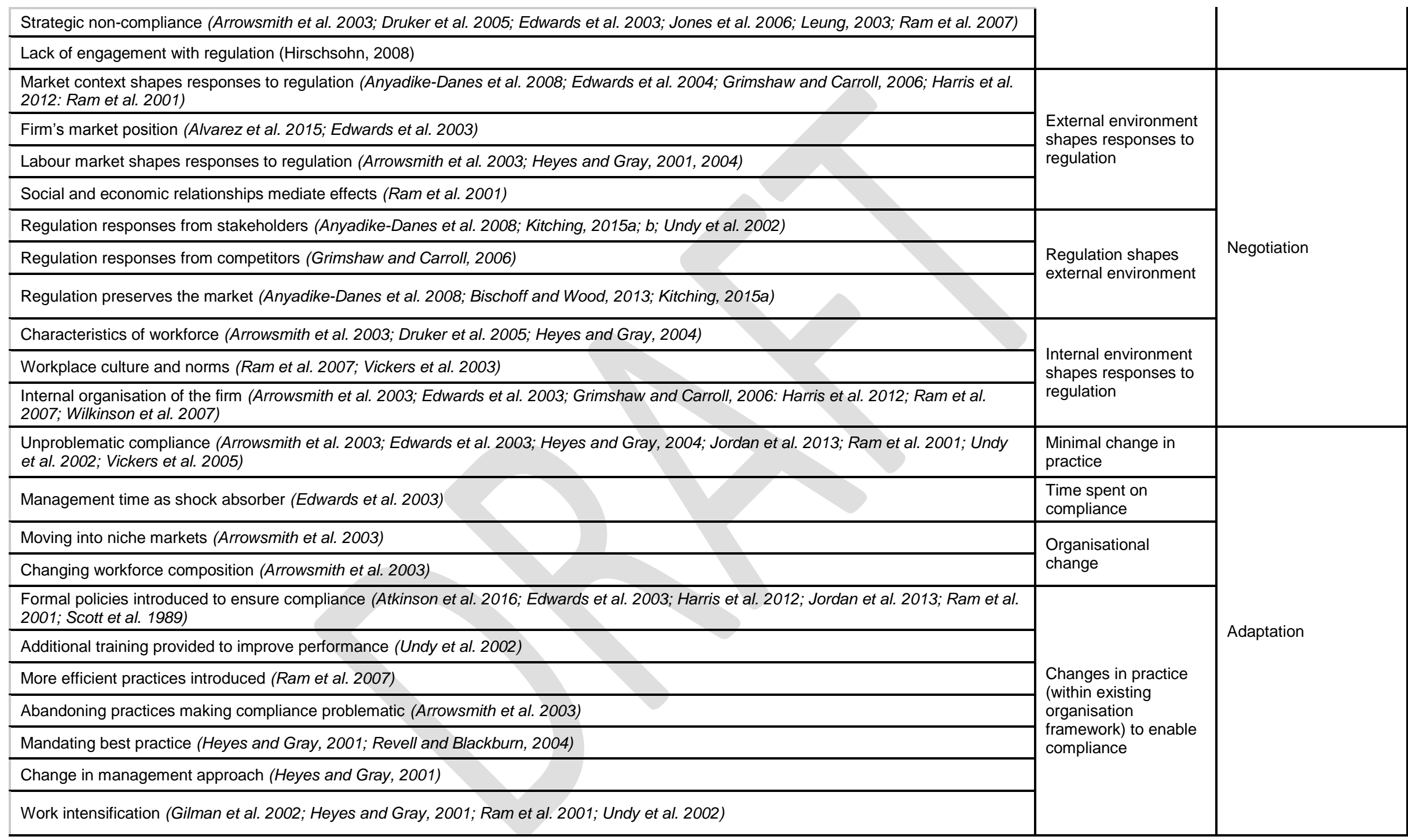

\section{Table 2: Thematic analysis}




\section{Findings}

Following the steps outlined above, our analysis generated four aggregate dimensions from insights gathered from extant literature: identification-interpretation; strategisation; negotiation; and adaptation (see Table 2). In this section, we conceptualise and develop each dimension with the objective of developing a conceptual framework to answer the central question of how regulations affect SMEs.

\section{Identification-interpretation}

SMEs are often subject to, rather than shapers of, their external environment. They tend to have limited resources and as such regulations are 'competing' for owner-manager attention among other external and internal factors. In such scenarios, owner-managers cannot be expected to identify everything of relevance from the external environment and incorporate it into the business. Nor would they be expected to apply the same level of emphasis or priority to everything they do identify.

We therefore use the term identification-interpretation to capture the processes through which SME decision-makers (often owner-managers) become aware of regulations that have potential relevance for the business and make sense of the implications those regulations might carry. We link the terms identification and interpretation to emphasise that the external environment is not scanned objectively or exhaustively but rather will be viewed through established priorities or views held by the owner-manager such that certain aspects of the environment will appear more relevant than others. The discovery practices involved in 'how, when and why employers seek to discover their legal obligations' are therefore a vital set of processes to understand (Kitching, 2016, p. 608). 
A key finding from qualitative studies that sheds light on the limitations of perception surveys is that owner-managers are often unsure about the details of specific regulations (e.g. Edwards et al. 2003; Vickers et al. 2003, 2005). A consequence of such partial awareness is that businesses might miss out on regulations that could help them, such as in relation to late payment (Anyadike-Danes et al. 2008). This partial awareness might also give rise to misunderstanding or vagueness around which regulations apply to a business and Vickers $e t$ al. (2003, p. 45) report that 'Only a few, mainly larger, enterprises were able to identify specific pieces of legislation that applied to their business.'

Knowledge of regulations with potential significance might be transmitted through sources such as business support (Vickers et al. 2003; Harris et al. 2012; Jordan et al. 2013; Kitching et al. 2015b; Kitching, 2016), regulators (Vickers et al. 2003; Revell and Blackburn, 2004; Hirschsohn, 2008), sector norms and informal networks (Hasle et al. 2012; Kitching, 2016) as well as employees' understanding of regulations (Harris, 2002; Atkinson et al. 2016). Kitching (2016, p. 613) demonstrates how such sources mediate the influence of regulations on SMEs 'by providing information and advice that constructs their image of the law.' Such advice and guidance is not necessarily about creating comprehensive compliance. Attention might be focused on particular concerns, such as dismissal of workers (Jordan et al. 2013), with small and micro businesses seeking information in response to critical events or problems (Jordan et al. 2013) and ensuring procedural compliance (Harris et al. 2012) rather than broader understanding of the issues regulated.

Identification-interpretation processes highlight how SME decision-makers' engagement with regulation is necessarily partial and informed by a range of perceptions as much as, if not more than, concrete experience. Whilst regulators might intend, or at least hope for, clarity in regulations to be transmitted into clearly understood relevance and associated implications, 
processes of identification-interpretation might serve to disconnect this intention from what is taken on-board at the firm level. Crucially, these interpretations, as well as the initial identification, will be tied to the business's strategic approach to regulations.

\section{Strategisation}

Consistent with how operations in SMEs are shaped by external influences more widely (Gill, 1985; Rainnie 1989), actors within businesses typically have some scope to decide on how to respond to regulation. We use the term strategisation to capture how actors, often ownermanagers, evaluate and exercise whatever degrees of discretion they might have in the face of regulatory requirements. Strategisation denotes the underlying purpose and drivers of a business which, in turn, carry implications for the kinds of response that might appear open to it, for example in how it will alter its practices. It is therefore primarily focused on the orientation of the business towards degrees of compliance and, in turn, shapes the negotiations around how the business will adapt in response to regulatory changes. However, as we will discuss below, and reflecting the non-linear nature of the analytical categorisation of these processes, this may also feed into the identification-interpretation practices in the business.

The significant role often played by owner-managers in SMEs means that their values and views on matters, such as wage rates and staff effort (Grimshaw and Carroll, 2006) or fair treatment of workers (Jordan et al. 2013), carry influence over whether and how regulatory requirements might be addressed. More broadly, the prevailing views of influential reference groups, such as those reflected by sector norms, can also shape how businesses orient themselves in relation to regulations. Central to this strategisation for many owner-managers is the informality and flexibility in the ways their businesses operate, drawing on informal networks and ad hoc management practices. Wilkinson et al. (2007) report how managers found the language and generally collectivist tone of European employment regulations 
‘unpalatable and even alien' (p. 1294) with implications for how they interpreted workplace regulations. In terms of the strategies adopted, Harris (2002) emphasises the importance of close, informal working relations and that owner-managers 'feared that a greater emphasis on "the rule book" could place these in jeopardy' (p. 302).

Harris (2002) suggests a typology of owner-managers who are unaware, aware/reactive, aware/proactive and aware/innovative regarding regulation (c.f. Vickers et al. 2003). What Harris (2002) views as a lack of awareness of specific regulation may represent a failure of identification-interpretation processes. However, reported unawareness may also reflect a particular reactive strategy whereby regulations are avoided. Avoidance of regulations refers to a strategic decision, or set of decisions, whereby a business via legal means moves itself out of the scope of regulations that might otherwise apply. Jordan et al. (2013) report, for instance 'that some employers were starting to avoid the regulation by using fixed-term contracts, despite being unable to let staff go at short notice should they no longer require the resource' (pp. 23-4).

However, as Bischoff and Wood (2013) explain, there might be a fine and somewhat uncertain distinction between avoiding regulations and evading them. Evasion of regulation refers to a strategic decision, or set of decisions, whereby a business moves itself out of the scope of regulations, and their enforcement, through illegal means. While some of the strategies detected by Bischoff and Wood (2013) in South African manufacturing businesses were efforts to avoid the effects of particular regulations, for example by remaining a small business, other examples such as under-reporting of employee numbers to industry Bargaining Councils suggest evasive practices. Evading regulations has been justified by reasons of intensely competitive markets (Leung, 2003; Jones et al. 2006), perceived irrelevance of particular regulations (Edwards et al. 2003) and the difficulties of complying with the regulations (Ojo et al. 2013). However, just 
as strategies of avoidance and evasion might co-exist in a business, so might the engagement with formal and informal economic activities. Resorting to participation in the informal economy through evasive practices is unlikely to reflect a complete shift out of the formal economy. Instead, as demonstrated by Ram et al. (2007), who studied UK clothing and catering businesses, a blurring might occur whereby identifying breaches in minimum wage regulations was complicated by the use of piece-rates, a tradition of unpaid overtime and views of fairness within the business.

Reactively responding to regulations by ensuring minimal compliance is typically presented as the low-risk response for SMEs (Druker et al. 2005; Jordan et al. 2013). Lynch-Wood and Williamson (2014) report that, concerning environmental regulations, the vast majority of manufacturing respondents who, with a lack of available resources, were 'natural compliers' (p. 473), focused on doing what was required rather than anything less or more. In this way, businesses accept regulatory compliance as part of doing business and take steps (such as engaging with relevant support services) to ensure their compliance.

Elsewhere the literature features evidence of businesses deploying a more proactive stance towards regulations, whereby they are engaged with the specifics of regulations and have greater expertise in determining their responses (Harris, 2002). Leung (2003), for example, studied the effects of rules around immigration on restaurants in Germany, identifying how the businesses proactively monitored and responded to regulations that influenced the workers they could recruit such as adjusting the types of food served to justify hiring chefs of relevant nationalities. Terjesen and Elam's (2009) case studies of four transnational entrepreneurs highlight the selection of business models and institutional environments to best achieve business objectives (see also Williamson et al. 2006). In contrast to reactive avoidance of 
regulations, here the businesses developed proactive strategies that ensure compliance and actively embed it in their business model and decision-making processes.

Harris (2002) suggests more innovative approaches as distinct from these proactive strategies, where the steps taken to proactively ensure compliance involve innovations to business operations or product offerings. Innovations might include the introduction of new technology but our review identified little supporting evidence for this strategic orientation. For example, Druker et al.'s (2005) findings were unable to differentiate between proactive and innovative responses (see also, Grimshaw and Carroll, 2006). The circumstances in which such strategic orientations might develop, and how they could be supported, therefore requires further research.

While strategising exists in recognition of the options available to owner-managers responding to regulations, these options might be constrained by the resources available, such as 'finance, equipment, management capability, workforce knowledge and skills' (Anyadike-Danes et al. 2008, p. 134). Druker et al. (2005) argue that strategies have to be contextualised by the 'preexisting business perspective or strategy and style, with market conditions and position setting the framework' (p. 20). While, as Kitching et al. (2015a, p. 136) observe, 'even severely resource-constrained firms possess some discretion regarding whether and how to adapt [to regulation]', possessing discretion should not be mistaken for unconstrained choice. Crucially, responses to regulation will engage in processes of negotiation.

\section{Negotiation}

Implementing planned responses to regulations requires processes of adjustment as a business negotiates with relevant interests, influences and other stakeholders. The intended strategic response to regulation might therefore not be implemented wholly as desired. Here we describe as negotiation those instances where decision-makers (again, often the owner-manager) have 
to account for factors in the external and internal environments that have a bearing on the business's ability to pursue the intended strategy in response to regulation.

As demonstrated by Ram et al. (2001), the social and economic relationships in which SMEs are embedded can mediate the impacts of regulation. For example, the biggest influence on the businesses Ram et al. studied was not the regulatory shock of a national minimum wage but the product markets in which they operated. These produced relatively stable conditions for restaurants but worsening conditions for clothing businesses where work intensification was used to cope with increased costs. Anyadike-Danes et al. (2008) studied taxi operators and suggest how regulated licensing may encourage greater use of taxis as consumers come to view them as a relatively safe mode of transport, rather than a sector dominated by unlicensed operators. Alvarez et al. (2015) provide a case study of an SME that, as industry-leader, shaped regulations that formalised America's king crab fishing industry. Such formalisation may encourage compliance of new entrants who wish to benefit from the protections or other advantages (such as customer perceptions) but may also, where entry barriers (such as complex licensing requirements) emerge, offer protection for SMEs by deterring would-be rivals. In each of these cases, the strategic orientation of SME decision-makers to regulations is negotiated within the specific product markets in which they operate.

Labour markets have also been found to exert influence over responses to regulations. In their study of SMEs in the UK's textiles and clothing industry, Heyes and Gray (2001) indicate how concerns over their ability to recruit, retain and motivate workers led to businesses foregoing an opportunity to pay the NMW 'development' rate to younger workers. Such cases reflect anticipated difficulties in negotiating a path through external labour market conditions and subsequent working arrangements within the business, effectively taking some strategies off the table. Elsewhere, Arrowsmith et al. (2003) found that different degrees of labour market 
pressures created a variety of negotiated responses among businesses across several different sectors. While tight margins limited scope for wage increases, managers sought to attract and retain workers through flexibility around working times while avoiding upward pressures on wages implied by the NMW. Regulations therefore interact with other aspects of a business' external environment in direct and indirect ways, creating complexity and variation in effects.

These examples also demonstrate the importance of a business' internal environment, for example in negotiating changes to working arrangements. The ability of businesses to flex work patterns and hours as a way of negotiating the challenges posed external factors emphasises the importance of informality in the internal operations of many SMEs. SMEs, and small businesses in particular, are noted for relatively high degrees of informality in how they are organised internally (Edwards et al. 2003), granting some flexibility in how necessary adjustments can be made in respect of regulations (Grimshaw and Carroll, 2006). Both Ram et al. (2007) and Vickers et al. (2003, p. 53) demonstrate the centrality of negotiation here, reporting how 'A significant number of managers emphasised the difficulty they often experienced in persuading their staff to observe safe practice and adhere to the legal requirements.'

Highlighting the processes of negotiation by which responses to regulation are developed, externally and internally, emphasises the ways in which strategies are not implemented on a blank slate or isolated from pre-existing conditions. Adopting a strategy in practice requires forms of negotiation, making adjustments or encountering practical constraints through processes of implementation. Unveiling processes of negotiation in response to regulations, qualitative studies rooted in wider understandings of SMEs demonstrate how businesses' responses to regulation are varied and complex, often reflecting the ways in which SMEs are embedded in networks of influence in different ways (Ram et al. 2001; Edwards et al. 2006). 


\section{Adaptation}

The term adaptation (after Kitching et al. 2015a) refers to the processes by which SMEs enact changes in practices in response to regulations. The term represents the different and varying effects of regulations on businesses, along with the variety that can be found in businesses' responses and outcomes. Processes of adaptation reflect a range of different scales of response, from minimal changes in practice through to more significant changes with wider implications.

Contrary to many arguments about compliance costs and the damage inflicted by regulations on the prosperity of SMEs (Chittenden et al. 2002), adaptation to regulations will not always be significant. For example, where new regulations such as a NMW or working time regulations are relevant to businesses, compliance may nonetheless require minimal or no change to existing practices. When compliance costs and resource implications are low, for example where only a small proportion of staff are affected, regulatory requirements can be accommodated with little additional effort, for example absorbed within management time (Edwards et al. 2003; Jordan et al. 2013). Heyes and Gray (2001) and Arrowsmith et al. (2003) report minimal impacts on wage bills or structures in the businesses they studied, although it is always vital to acknowledge variations, even within particular industries (Undy et al. 2002). Nonetheless, several of the studies reviewed identified instances where regulations were adopted readily in practice and taken-for-granted such that owner-managers or employees might not report these practices as a form of compliance.

More significant adaptations may be enforced by regulations that mandate particular practices to improve operations within the businesses. For example, Revell and Blackburn's (2004) study of the construction industry found that legislation was viewed 'as the real stimulant of environmental reform within the sector', despite resistance to the bureaucracy involved (p. 32). Similarly, they found that health and safety inspections of restaurants were generally viewed 
positively where owner-managers appreciate the value of stringent hygiene standards. It is also important to recognise that, in response to the NMW, many workers' pay increased (Heyes and Gray, 2001).

More extensive adaptations are also reported in the literature regarding changes in practices to enable compliance. For example, some clothing businesses studied by Arrowsmith et al. (2003) 'were able to respond to the pressures of deteriorating business and the NMW by making a shift to specific niche markets' that focused on higher-value, low-volume customised products (p. 445). Taking such a step carried implications for job losses and increases in training investment for staff, underlining the transformational nature of such adaptations. More commonly, introducing formal practices to ensure compliance in areas of business practice has been reported. Scott et al. (1989) found that, in many areas, regulation 'encourages management discipline and systems, and should stabilise important areas such as grievances, discipline and dismissal, as well as ensure more attention to recruitment and training policies' (p. 97). The move towards greater degrees of formality in response to regulations should be encouraging for those who argue for the importance of formal policies and practices to SME growth and success (Phelps et al. 2007). However, it must be acknowledged that the drivers for, and responses through, formalisation cannot be assumed to reflect standardisation of practices across SMEs (Jordan et al. 2013) nor does the adoption of greater formality necessarily remove owner-managers' preference for informality in operations (Harris et al. 2012; Atkinson et al. 2016).

Adapted practices can also be more regressive where they introduce work intensification (Ram et al. 2001; Undy et al. 2002) and other measures that seek to offset the effects of increased wages through asking more of employees, for example changing how wages are calculated or removing paid work breaks (Gilman et al. 2002). The contrast in how adaptations may be 
experienced by workers (e.g. between those receiving additional training and those losing paid breaks) suggest the ways in which factors such as the product or labour markets shape important variations in how businesses might strategise, negotiate and, ultimately, adapt to specific regulations and therefore how outcomes may vary over time.

\section{Discussion and research agenda}

The prevalence and significance of SMEs in economies around the world has directed attention towards factors that might hinder or support their viability and growth, leading to a significant focus on regulations. Research, including surveys of owner-manager perceptions, crosscountry comparisons and compliance costs, has been used to argue that regulations affect SMEs disproportionately and negatively (Chittenden et al. 2002). These studies have made important contributions but, nonetheless, suffer significant limitations (as outlined above). These limitations risk distorting debates about regulatory policies.

To generate insights from an alternative perspective, we conducted a systematic literature review of qualitative research to answer the research question 'how do regulations affect SMEs?' Qualitative research tends to pursue detailed, in-depth studies that are attentive to the heterogeneity of SMEs and their contexts in exploring the dynamic and varied effects of regulation, potentially overcoming the limitations of larger-scale studies. Our analysis and synthesis of the existing qualitative research generated a conceptual framework consisting of four processes involved in how regulations affect SMEs: identification-interpretation; strategisation; negotiation; and adaptation. In this section, we discuss the implications of the

conceptual framework and identify future directions for research stemming from this processual, interconnected and embedded perspective.

Processual understandings of how regulations affect SMEs 
Our conceptual framework emphasises the importance of adopting a processual view (Kitching and Smallbone, 2010) to develop a richer understanding of how regulations affect SMEs. Firstly, our framework highlights how quantitative studies, such as surveys of owner-manager perceptions or cross-country comparisons, that rely on inferences drawn from aggregated data, can obscure the complex ways that SMEs engage with and adapt to regulations, which in-turn, can influence how regulations affect SMEs on an ongoing basis. A processual approach, by contrast, 'put[s] movement, change and flow first; to study processually is to consider the world as restless, something underway, becoming and perishing, without end' (Hjorth et al. 2015 p. 599). This is reflected in each of the four processes we have identified.

Studies that survey owner-manager perceptions will capture some insights into identificationinterpretation processes. However, survey responses are separated from the broader, ongoing processes involved in becoming aware of regulations that have potential relevance for the business and making sense of their implications. Reported owner-manager perceptions are not the same as effects. The discovery practices involved in 'how, when and why employers seek to discover their legal obligations' are therefore a vital set of processes to understand (Kitching, 2016, p. 608) and would benefit from further research. For example, the factors that determine which regulations are identified and why (not), how the interpretation of particular regulations is shaped, including where misunderstandings may occur. There is also a need to understand how the perceptions of regulations have effects themselves, as well as effects outside of the owner-manager's perceived interpretation.

Considering how these processes unfold provides an opportunity to examine how responses to regulations are made and, in-turn, responded to. Owner-managers and others within SMEs are not simply subjected to regulations, they can exert agency in how they respond to particular requirements. Strategisation is a way of conceptualising the potential for exercising discretion 
and how it might shape the effects of regulations. The possibility of discretion is often obscured by quantitative studies yet different strategies (e.g. evade, avoid, proactively engage) are a crucial part of understanding the effects of regulations. The complexity of decision-makers' orientations, how they are shaped by norms and values and influences within and external to the business as well as how they play out in practice is another area in need of further, detailed research.

We have also identified processes of negotiation that reflect the ways in which strategies might be constrained (or potentially developed). These processes help to further elaborate the importance of external factors, such as product and labour markets, as well as internal factors such as management style and everyday practices. In part, these processes of negotiation highlight the importance in developing more sophisticated understandings of how processes are embedded and this is something we return to in greater detail below.

The final processes captured in our conceptual framework are those of adaptation (Kitching et al. 2015a) which range from practices that continue unchanged to the more extensive changes that might occur in a business, including as an ongoing part of what Steyaert (2007) refers to as 'entrepreneuring' processes. Importantly, these changes include not only those mandated by the regulation (e.g. an increase in wages) or as a result of compliance costs, but also a more detailed understanding of the potential indirect effects, including the benefits of regulation that have been largely ignored in the literature. A processual approach highlights that there is not a simple, direct or intended consequence, nor that such effects have a single, 'final' outcome. Instead, the effects of regulations on SMEs should be characterised as processes that unfold over time rather than 'one shot' responses such as to comply or evade. This variation is significant but often ignored by studies that seek to aggregate or provide blanket messages 
about the relationship between regulation and SMEs; processes of adaptation require significant further study.

Empirically, processual approaches involve research that 'follows things, it is phenomenadriven, sensitive to the appearing and re-appearing of events woven with actions, material things, structures and values that cohere in patterns of directionality' (Hjorth et al. 2015, p. 600). Such an empirical agenda also suggests that alternative theoretical perspectives are needed to understand the effects of regulation, as have begun to emerge more generally in relation to entrepreneurship (Steyaert, 2007). For example, Van de Ven and Poole (1995) broadly group different approaches to theorising processes in terms of life cycles, teleology, dialectics and evolution and each have potential implications for understanding how regulations affect SMEs (e.g. in terms of recurrent, cumulative changes produced and theorised in an evolutionary approach). Such theoretical starting points offer potentially valuable perspectives; they also emphasise a need to consider processes not in isolation but within an interconnected framework and as embedded.

\section{Processes as interconnected}

The processes captured by our conceptual framework are analytical distinctions, responding to regulations may not follow discrete, ordered stages from identification to adaptation. The framework is not, therefore, presented to imply a sequential development but rather as a collection of processes that overlap and inform each other. The extent of such interconnectedness is not revealed in detail by our synthesis of existing studies because it has not received significant attention, but emerging insights from this literature review are suggestive of the importance of this perspective and indicate a future research agenda.

Viewing processes as interconnected recognises their interplay. For example, processes can act as 'generating mechanisms' (Van de Ven and Poole, 1995, p. 528) that create their own effects, 
which include 'critical events and turning points, contextual influence, formative patterns that give overall direction to the change, and causal factors that influence the sequencing of events' (Van de Ven and Poole, 2005, p. 1384). Strategic decisions to evade certain regulations, for example, could create particular demands for how the associated practices are negotiated within the business. Moreover, the attitudes held by an owner-manager towards identificationinterpretation or strategisation might be influenced by experiences stemming from previous adaptations. A lack of enforcement action allowing them to 'get away' with non-compliance previously might relax attitudes and energies devoted to identification-interpretation activities or embolden evasion and so on.

This sense of the non-linearity, complexity and potential messiness involved in how regulations affect SMEs risks being smoothed out or ignored by many of the studies that dominate the field. We suggest the importance of moving beyond studying specific processes (e.g. strategisation) in isolation but understanding how they are shaped by other processes (e.g. identification-interpretation that informs these strategies, or the ways in which constraints on the strategies are negotiated). This could include studying processes as generating mechanisms but also to taking more holistic approaches to the different ways in which business operations and decision-makers interact with regulations over time.

\section{Processes as embedded}

In developing our conceptual framework, the importance of understanding these processes as embedded in a wider context emerges as being important to understanding how regulations affect SMEs. Studies of SMEs more generally have emphasised the importance of embedding them in their contexts (Curran and Stanworth, 1981; Edwards et al. 2006; Gilman and Edwards, 2008). Similarly, debates over the effects of regulation, especially the burdens of regulation, need to be located in a context whereby the regulations are one factor among many that have a 
bearing on actions and outcomes for SMEs (Ram et al. 2001; Arrowsmith et al. 2003). Outcomes are not determined by single influences or simple sets of influences, such as 'regulation' or 'red tape' (Rainnie, 1989) although this can sometimes be the impression given by studies of business regulations. The ways in which SMEs are differently embedded in relation to external (product markets, labour markets, family networks) and internal factors (resources, strategic choice, rules, management style) shape a variety of responses to influences such as new regulations (Edwards et al. 2006; see also Gilman and Edwards, 2008). We therefore highlight a need to re-embed a processual analysis of SMEs and not treat regulations as isolated or unmediated.

Setting out a broad perspective on embeddedness, Zukin and DiMaggio (1990) take it 'to refer to the contingent nature of economic action with respect to cognition, culture, social structure, and political institutions.' In this light, regulations do not 'enter' a business in a straightforward manner but rather the processes and subsequent impacts are contingent upon a range of other influences. The contingency relates, for example, to the subjective nature of processes that are open to a range of influences, pressures and sources of advice.

Emphasising the importance of structural embeddedness, Uzzi (1997) explores the operation of close social relationships, 'embedded ties', in economic exchange beyond the bounds of more numerous 'market relationships' (or 'arms-length ties'). The social structures within which a business is linked to others in its external environment carry implications for how those businesses operate; enabling as well as constraining operations. The effects of regulations could be shaped by, for instance, the availability of trusted workers or business associates to produce counterfeit goods in response to problems posed by market pressures and regulatory requirements (see Ram et al. 2001). A key part of the value of detailed qualitative studies is the possibility of researching such social structures in much greater depth. 
While Zukin and DiMaggio (1990) acknowledge the primacy of social structure, their work highlights that scope remains for engaging with other forms of embeddedness that can influence the effects of regulations: the cognitive embeddedness of an owner-manager, for example to identify relevant regulations and understand how they might be responded to (Edwards et al. 2003; Vickers et al. 2005); culturally-embedded norms about appropriate conduct and acceptable responses to regulations (Vickers et al. 2003, 2005; Ram et al. 2007); and the political embeddedness of a business could influence the relative power of managers and employees to access accurate information on employment rights and protect these in practice (Atkinson et al. 2016). Each of these areas offers potential lines for future research that could advance both empirical and theoretical insights into the effects of regulations on SMEs.

\section{Methodological development}

To pursue the research agenda set out in the development of our conceptual framework, we suggest a need for methodological development. A processual, interconnected and embedded approach highlights the layered and complex ways that regulations affect SMEs. Studying these effects requires research approaches that get close to the practices associated with regulations and SMEs. Further, our analysis indicates considerations that are not readily captured and explored in studies focused on owner-manager perceptions, cross-national variations or compliance costs.

In-depth, qualitative studies are required to more fully explore the indirect effects of regulations and how regulations interact with other forms of influence. Recently, steps to understand regulations and the responses of small businesses situated in particular contexts have been proposed by Mayson and Barrett (2017). Drawing on Uzzi (1997) and incorporating Weick's work on sensemaking, Mayson and Barrett 'seek to explain why adaptation occurs and how it 
does.' (2017, p. 191). To achieve this, Mayson and Barrett propose a research methodology that appreciates a business' context and is centred on interviewing owner-managers. While acknowledging the importance of owner-managers in SME operations, we suggest incorporating additional data collection methods such as ethnographies and observations (e.g. Ojo et al. 2013), interviews with employees (Ram et al. 2007) and external parties (e.g. Bischoff and Wood, 2013). Enriching data collection approaches could help avoid overreliance on owner-managers who might lack detailed knowledge of regulations (Clifton and Tatton-Brown, 1979; Marlow, 2003; Hart and Blackburn, 2005), the ability to enforce their desired responses and a full appreciation of the consequences of their decisions (Kitching et al. 2015b).

Our focus on qualitative studies in this review reflects the nature of our research question and a need to 're-balance' the evidence underpinning current debates, it is not to suggest that all research should be of this type. Rather, we embrace how diverse and innovative approaches to studying processes emerge depending upon different epistemological and ontological assumptions (Van de Ven and Poole, 2005). While this likely leads to debates about appropriate methodologies or which insights are of value, a range of theoretical and methodological approaches is clearly required to address the research agenda suggested by our findings. For example, Kitching et al. (2015a, p. 142), discussing broader questions of performance, adopt a critical realist approach, arguing that this allows them access to 'the real, actual and empirical levels of social reality in order to show that regulation possesses diverse causal powers and generates a range of performance effects at the micro-level of the individual small enterprise.' To explore these processes, researchers need to explore alternatives to owner-manager accounts which have, in surveys and qualitative interviews, dominated our understanding of the effects of regulations. 
To further empirically explore the interconnected processes through which regulations affect SMEs, longitudinal studies are required that are attentive to how effects might change over time and how they are interconnected, overlap and influence each other. Businesses, especially those that are growing, can encounter different concerns, for example, becoming more formal, changing rules and routines or management style, interacting with different stakeholders and encountering new operating environments (Phelps et al. 2007; Mallett and Wapshott, 2014). It is important to study how regulations affect SMEs as the organisations and their operating environments change (Carter et al. 2009); evidence seeking to understand the effects of regulation needs to accommodate this.

Detailed, longitudinal analysis is necessary to disentangle the complexities involved in attempting the cost-benefit analysis and that has been influential in the development of 'better regulation' by policy-makers. For example, while the formalising of practices to ensure compliance incurs short-term costs (such as hiring legal advisers to develop policies), these costs may be offset by the longer-term benefits of compliance and the potential benefits of the practices themselves. Research should be conducted to develop robust, replicable methodologies to fully assess both the costs and benefits of regulations over time. This level of detail and theoretical and methodological innovation is required if we are to fully understand how regulations affect SMEs.

\section{Conclusion}

The systematic literature review presented in this article has identified, analysed and synthesised qualitative research seeking to explore how regulations affect SMEs. Analysing these qualitative studies has highlighted the often complex and messy processes that characterise how SMEs engage with regulation. An especially valuable aspect of qualitative studies in this area is their ability to get 'inside' the businesses and unpack the 'black box', 
shedding light on how SMEs get to grips with regulations (Kitching and Smallbone, 2010) and to re-embed them within complex networks of relationships and influences (Edwards et al. 2006). Our synthesis of qualitative research has generated a conceptual framework consisting of four key processes that are interconnected and embedded. Through this conceptual framework we have opened-up the complexities of how regulations affect SMEs.

The effects of regulation are not always direct, predictable or constraining. Instead, studies show how regulations vary in terms of relevance and significance for businesses, can offer competitive opportunities or protections and, ultimately, carry variable consequences. Moreover, it is apparent that regulations might be addressed in different ways by businesses. Insightful qualitative accounts of how SMEs engage with regulations, especially the ways that responses are formulated and implemented, highlight the scope for further consideration of the processes involved. To fully understand the variation and complexity, there is a clear need for further research that explores in-depth the processual, embedded nature of how regulations affect SMEs.

Such studies have a contribution to make in policy discussions, which have shown significant interest in the effects of regulations on SMEs, by highlighting the variation of outcomes that runs through these studies. There are opportunities to advance discussions beyond a narrow framing of regulations as simply burdensome on SMEs and counter to business interests, and wider political-economic agendas (Edwards et al. 2003; Doern, 2009). Qualitative researchers have reframed SMEs as engaging actively with regulations, among other factors encountered when operating a business, in a wide variety of ways. They enable debates to move beyond consideration of 'regulation' as an isolated, negative influence upon static and passive businesses comprising a homogenous SME constituency. Rather, SMEs' engagement with 
regulations should be understood as interconnected, embedded processes that give rise to varied challenges, responses and outcomes. 


\section{References}

ABS (2015). Journal quality guide. London: Association of Business Schools

Adams, R., Jeanrenaud, S., Bessant, J., Denyer, D. and Overy, P. (2016). Sustainabilityoriented innovation: a systematic review. International Journal of Management Reviews, 18, pp. 180-205.

Alvarez, S.A., Young, S.L. and Woolley, J.L. (2015). Opportunities and institutions: a cocreation story of the king crab industry. Journal of Business Venturing, 30, pp. 95-112.

Anyadike-Danes, M., Athayde, R., Blackburn, R., Hart, M., Kitching, J., Smallbone, D. and Wilson, N. (2008). The Impact of Regulation on Small Business Performance: Report for the Enterprise Directorate of BERR. London: Department of Business, Enterprise and Regulatory Reform.

Arrowsmith, J., Gilman, M. W., Edwards, P. and Ram, M. (2003). The impact of the national minimum wage in small firms. British Journal of Industrial Relations, 41, pp. 435-456.

Atkinson, C., Mallett, O., \& Wapshott, R. (2016). 'You try to be a fair employer': regulation and employment relationships in medium-sized firms. International Small Business Journal, 34, pp. 16-33.

Baldacchino, L., Ucbasaran, D., Cabantous, L. and Lockett, A. (2015). Entrepreneurship research on intuition: a critical analysis and research agenda. International Journal of Management Reviews, 17, pp. 212-231.

Barrett, R., Mayson, S. and Bahn, S. (2014). Small firms and health and safety harmonisation: potential regulatory effects of a dominant narrative. Journal of Industrial Relations, 56, pp. 6280 .

Baumol, W.J. (1990). Entrepreneurship: productive, unproductive, and destructive. Journal of Political Economy, 98, Part 1, pp. 893-921.

Bhatt, B., Qureshi, I. and Riaz, S. (2017). Social entrepreneurship in non-munificent institutional environments and implications for institutional work: insights from China. Journal of Business Ethics, doi:10.1007/s10551-017-3451-4, pp. 1-26.

Bischoff, C., and Wood, G. (2013). Selective informality: the self-limiting growth choices of small businesses in South Africa. International Labour Review, 152, pp. 493-505.

Bozeman, B. (1993). A theory of government 'red tape'. Journal of Public Administration Research and Theory, 3, pp. 273-303.

Capelleras, J.L., Mole, K.F., Greene, F.J. and Storey, D.J. (2008). Do more heavily regulated economies have poorer performing new ventures? Evidence from Britain and Spain. Journal of International Business Studies, 39, pp. 688-704.

Carter, S., Mason, C. and Tagg, S. (2009). Perceptions and experience of employment regulation in UK small firms. Environment and Planning C: Government and Policy, 27, pp. 263-278. 
Cassell, C., Nadin, S., Gray, M. and Clegg, C. (2002). Exploring human resource management practices in small and medium sized enterprises. Personnel Review, 31, pp. 671-692.

Chittenden, F., Kauser, S. and Poutziouris, P. (2002). Regulatory burdens of small business: a literature review, London: Small Business Service Research Directorate.

Chittenden, F., Kauser, S. and Poutziouris, P. (2003). Tax regulation and small business in the USA, UK, Australia and New Zealand. International Small Business Journal, 21, pp. 93-115.

Chittenden, F., Iancich, S. and Sloan, B. (2009). Techniques available for estimating the impact of regulations. In Nijsen, A., Hudson, J., Müller, C., van Paridon, K. and Thurik, R. (eds), Business Regulation and Public Policy, New York: Springer, pp.43-59.

Clifton, R. and Tatton-Brown, C. (1979). Impact of Employment Legislation on Small Firms. Research Paper No. 6. London: Department of Employment.

Curran, J. and Stanworth, J. (1981). The social dynamics of the small manufacturing enterprise. Journal of Management Studies, 18, pp. 141-158.

Denyer, D. and Tranfield, D. (2006). Using qualitative research synthesis to build an actionable knowledge base. Management Decision, 44, pp. 213-227.

Djankov, S. (2009). The regulation of entry: a survey. World Bank Research Observer, 24, pp. 183-203.

Djankov, S., La Porta, R., Lopez-de-Silanes, F. and Shleifer, A. (2002). The regulation of entry. Quarterly Journal of Economics, 117, pp. 1-37.

Doern, R. (2009). Investigating barriers to SME growth and development in transition environments a critique and suggestions for developing the methodology. International Small Business Journal, 27, pp. 275-305.

Druker, J., White, G. and Stanworth, C. (2005). Coping with wage regulation: implementing the national minimum wage in hairdressing businesses. International Small Business Journal, 23, pp. 5-25.

Edwards, P., Black, J. and Ram, M. (2003). The Impact of Employment Legislation on Small Firms: A Case Study Analysis. London: Department of Trade and industry.

Edwards, P., Ram, M. and Black, J. (2004). Why does employment legislation not damage small firms? Journal of Law and Society, 31, pp. 245-265.

Edwards, P., Ram, M., Gupta, S.S. and Tsai, C.J. (2006). The structuring of working relationships in small firms: towards a formal framework. Organization, 13, pp. 701-724.

European Commission (no date). The Small Business Act for Europe. Available at: https://ec.europa.eu/growth/smes/business-friendly-environment/small-business-act_en. Accessed 11/02/2018.

European Union (2015). User Guide to the SME Definition. Luxembourg: Publications Office of the European Union. 
Gill, J. (1985). Factors affecting the survival and growth of the smaller company. Aldershot: Gower.

Gilman, M.W. and Edwards, P.K. (2008). Testing a framework of the organization of small firms: Fast-growth, high-tech SMEs. International Small Business Journal, 26, pp. 531-558.

Gilman, M., Edwards, P., Ram, M. and Arrowsmith, J. (2002). Pay determination in small firms in the UK: the case of the response to the National Minimum Wage. Industrial Relations Journal, 33, pp. 52-67.

Gioia, D.A., Corley, K.G. and Hamilton, A.L. (2013). Seeking qualitative rigor in inductive research: notes on the Gioia methodology. Organizational Research Methods, 16, pp.15-31.

Grimshaw, D. and Carroll, M. (2006). Adjusting to the national minimum wage: constraints and incentives to change in six low-paying sectors. Industrial Relations Journal, 37, pp. 2247.

Grunhagen, M. and Berg, H. (2011). Modelling the antecedents of innovation-based growth intentions in entrepreneurial ventures: the role of perceived regulatory conditions in the German renewable energies and disease management industries. International Journal of Technology, Policy and Management, 11, pp. 220-249.

Hahn, R.W. (1998). Policy watch: government analysis of the benefits and costs of regulation. The Journal of Economic Perspectives, 12, pp. 201-210.

Harden, A. and Thomas, J. (2005). Methodological issues in combining diverse study types in systematic reviews. International Journal of Social Research Methodology, 8, pp. 257-271.

Harris, L. (2000). Employment regulation and owner-managers in small firms: seeking support and guidance. Journal of Small Business and Enterprise Development, 7, pp. 352-263.

Harris, L. (2002). Small firm responses to employment regulation. Journal of Small Business and Enterprise Development, 9, pp. 296-306.

Harris, L., Tuckman, A. and Snook, J. (2012). Supporting workplace dispute resolution in smaller businesses: Policy perspectives and operational realities. The International Journal of Human Resource Management, 23, pp. 607-623.

Hart, M. and Blackburn, R. (2005). Labour regulation and SMEs: A challenge to competitiveness and employability? In Marlow, S., Patton, D. and Ram, M. (eds), Managing Labour in Small Firms, London: Routledge, pp. 72-86.

Hasle, P., Limborg, H.J., Kallehave, T., Klitgaard, C. and Andersen, T.R. (2012). The working environment in small firms: responses from owner-managers. International Small Business Journal, 30, pp. 622-639.

Heyes, J. and Gray, A. (2001). The impact of the national minimum wage on the textiles and clothing industry. Policy Studies, 22, pp. 83-98.

Heyes, J. and Gray, A. (2004). Small firms and the National Minimum Wage: implications for pay and training practices in the British private service sector. Policy Studies, 25, pp. 209-225. 
Hirschsohn, P. (2008). Regulating the 'Animal Spirits' of entrepreneurs? Skills development in South African small and medium enterprises. International Small Business Journal, 26, pp. 181-206.

Hjorth, D., Holt, R. and Steyaert, C. (2015). Entrepreneurship and process studies. International Small Business Journal, 33, pp. 599-611.

HM Government (2011). One-in, One-out: Statement of New Regulation. Available at: https://www.gov.uk/government/collections/one-in-two-out-statement-of-new-regulation accessed 23/06/2016.

Holliday, R. (1995) Investigating Small Firms: Nice Work? London: Routledge.

Hoque, K. and Noon, M. (2004). Equal opportunities policy and practice in Britain: evaluating the 'empty shell' hypothesis. Work, Employment and Society, 18, pp. 481-506.

IFF Research (2012). SME Business Barometer June 2012. Report prepared for the Department of Business, Innovation and Skills, August 2012, URN 12/P75C.

Jones, T., Ram, M. and Edwards, P. (2006). Ethnic minority business and the employment of illegal immigrants. Entrepreneurship \& Regional Development, 18, pp. 133-150.

de Jong G, and Van Witteloostuijn A (2014). Regulatory red tape and private firm performance, Public Administration, 93, pp. 34-51.

Jordan, E., Thomas, A.P., Kitching, J.W. and Blackburn, R.A. (2013). Employment Regulation. Part A: Employer Perceptions and the Impact of Employment Regulation. London: Department for Business, Innovation and Skills.

Kistruck, G.M., Webb, J.W., Sutter, C.J. and Bailey, A.V. (2015). The double-edged sword of legitimacy in base-of-the-pyramid markets. Journal of Business Venturing, 30, pp. 436-451.

Kitching, J. (2016). Between vulnerable compliance and confident ignorance: small employers, regulatory discovery practices and external support networks. International Small Business Journal, 34, pp. 601-617.

Kitching, J., Hart, M. and Wilson, N. (2015a). Burden or benefit? Regulation as a dynamic influence on small business performance. International Small Business Journal, 33, pp. 130147.

Kitching, J., Kašperová, E. and Collis, J. (2015b). The contradictory consequences of regulation: The influence of filing abbreviated accounts on UK small company performance. International Small Business Journal, 33, pp. 671-688.

Kitching, J. and Smallbone, D. (2010). Literature Review for the SME Capability to Manage Regulation Project, Report for Inland Revenue. Auckland: Government of New Zealand.

Leung, M.W. (2003). Beyond Chinese, beyond food: unpacking the regulated Chinese restaurant business in Germany. Entrepreneurship \& Regional Development, 15, pp. 103-118.

Lynch-Wood, G. and Williamson, D. (2014). Civil regulation, the environment and the compliance orientations of SMEs. Journal of Business Ethics, 125, pp. 467-480. 
Mabey, C. (2013). Leadership development in organizations: multiple discourses and diverse practice. International Journal of Management Reviews, 15, pp. 359-380.

Mallett, O. and Wapshott, R. (2014). Informality and employment relationships in small firms: humour, ambiguity and straight-talking. British Journal of Management, 25, pp. 118-132.

Marlow, S. (2003). Formality and informality in employment relations: the implications for regulatory compliance by smaller firms. Environment and Planning C: Government and Policy, 21, pp. 531-547.

Marlow, S., Taylor, S. and Thompson, A. (2010). Informality and formality in medium-sized companies: contestation and synchronization. British Journal of Management, 21, pp. 954966.

Mayson, S. and Barrett, R. (2017). A new argument using embeddedness and sensemaking to explain small firms' responses to employment regulation. Human Resource Management Journal, 27, pp.189-202.

Mingers, J. and Willmott, H. (2013). Taylorizing business school research: on the 'one best way' performative effects of journal ranking lists. Human Relations, 66, pp. 1051-1073.

Moule, C. (1998). Regulation of work in small firms: a view from the inside. Work, Employment \& Society, 12, pp. 635-653.

Moynihan, D.P., Wright, B.E. and Pandey, S.K. (2012). Working within constraints: can transformational leaders alter the experience of red tape? International Public Management Journal, 15, pp. 315-336.

OECD (2017). Small, medium, strong. Trends in SME performance and business conditions. Paris: OECD Publishing.

OECD (no date). Glossary of Statistical Terms: Regulation. Available at: https://stats.oecd.org/glossary/detail.asp?ID=3295 Accessed 27/06/2017.

Ojo, S., Nwankwo, S. and Gbadamosi, A. (2013). Ethnic entrepreneurship: the myths of informal and illegal enterprises in the UK. Entrepreneurship \& Regional Development, 25, pp. 587-611.

Phelps, R., Adams, R. and Bessant, J. (2007). Life cycles of growing organizations: A review with implications for knowledge and learning. International Journal of Management Reviews, 9, pp. 1-30.

Rainnie, A. (1989). Industrial Relations in Small Firms: Small isn't Beautiful, London: Routledge.

Ram, M. (1994). Managing to Survive: Working Lives in Small Firms, Oxford: Blackwell.

Ram, M. (2000). Investors in People in small firms: case study evidence from the business services sector. Personnel Review, 29, pp. 69-91. 
Ram, M., Edwards, P., Gilman, M. and Arrowsmith, J. (2001). The dynamics of informality: employment relations in small firms and the effects of regulatory change. Work, Employment \& Society, 15, pp. 845-861.

Ram, M., Edwards, P. and Jones, T. (2007). Staying underground: informal work, small firms, and employment regulation in the United Kingdom. Work and Occupations, 34, pp. 318-344.

Revell, A. and Blackburn, R. (2004). SMEs and their response to environmental issues in the $U K$, Occasional Paper, No 57, Kingston Business School.

Rogoff, E.G., Lee, M-S. and Suh, D-C. (2004). 'Who done it?' Attributions by entrepreneurs and experts of the factors that cause and impede small business success, Journal of Small Business Management, 42, pp.364-376.

SBRT [no date]. Quarterly Survey of Small Business in Britain 1985-2014. Available at: http://business-school.open.ac.uk/research/quarterly-survey\# (accessed 02 February 2017).

Scott, M., Roberts, I., Holroyd, G. and Sawbridge, D. (1989). Management and Industrial Relations in Small Firms. Department of Employment Research Paper No. 70. London: HMSO.

Smallbone, D. and Welter, F. (2001). The role of government in SME development in transition economies. International Small Business Review, 19, pp. 63-77.

van Stel, A., Storey, D.J. and Thurik, A.R. (2007). The effect of business regulations on nascent and young business entrepreneurship. Small Business Economics, 28, pp. 171-186.

Steyaert, C. (2007). 'Entrepreneuring' as a conceptual attractor? A review of process theories in 20 years of entrepreneurship studies. Entrepreneurship and Regional Development, 19, pp. 453-477.

Terjesen, S. and Elam, A. (2009). Transnational entrepreneurs' venture internationalization strategies: a practice theory approach. Entrepreneurship Theory and Practice, 33, pp. 10931120 .

Thomas, J. and Harden, A. (2008). Methods for the thematic synthesis of qualitative research in systematic reviews. BMC Medical Research Methodology, 8, pp. 45-55.

Thorpe, R., Holt, R., Macpherson, A. and Pittaway, L. (2005). Using knowledge within small and medium-sized firms: a systematic review of the evidence. International Journal of Management Reviews, 7, pp. 257-281.

Tourish, D. and Willmott, H. (2015). In defiance of folly: journal rankings, mindless measures and the ABS guide. Critical Perspectives on Accounting, 26, pp. 37-46.

Tranfield, D., Denyer, D. and Smart, P. (2003). Towards a methodology for developing evidence-informed management knowledge by means of systematic review. British Journal of Management, 14, pp. 207-222.

Undy, R., Kessler, I. and Thompson, M. (2002). The impact of the national minimum wage on the apparel industry. Industrial Relations Journal, 33, pp. 351-364. 
Uzzi, B. (1997). Social structure and competition in interfirm networks: the paradox of embeddedness. Administrative Science Quarterly, 42, pp. 35-67

Van de Ven, A.H. and Poole, M.S. (1995). Explaining development and change in organizations. Academy of Management Review, 20, pp. 510-540.

Van de Ven, A.H. and Poole, M.S. (2005). Alternative approaches for studying organizational change. Organization Studies, 26, pp. 1377-1404.

Vickers I, Baldock R., Smallbone D. and James P. (2003). Cultural Influences on Health and Safety Attitudes and Behaviour in Small Businesses. Research Report no. 150, Health and Safety Executive, Norwich: HMSO.

Vickers, I., James, P., Smallbone, D. and Baldock, R. (2005). Understanding small firm responses to regulation: the case of workplace health and safety. Policy Studies, 26, pp. 149169.

Walsh, D. and Downe, S. (2005). Meta-synthesis method for qualitative research: a literature review. Journal of Advanced Nursing, 50, pp. 204-211.

Welsh, J.A. and White, J.F. (1981). A small business is not a little big business. Harvard Business Review, July-August, pp. 18-32.

Westrip, A. (1986). Small firms policy: the case of employment legislation. In Curran, J., Stanworth, J. and Watkins, D. (eds), The Survival of the Small Firm, Vol. 2: Employment, Growth, Technology and Politics, Aldershot: Gower Publishing Company Limited, pp.184203.

Wilkinson, A. (1999). Employment relations in SMEs. Employee Relations, 21, pp. 206-217.

Wilkinson, A., Dundon, T. and Grugulis, I. (2007). Information but not consultation: exploring employee involvement in SMEs. The International Journal of Human Resource Management, 18, pp. 1279-1297.

Williamson, D., Lynch-Wood, G. and Ramsay, J. (2006). Drivers of environmental behaviour in manufacturing SMEs and the implications for CSR. Journal of Business Ethics, 67, pp. 317330.

Willmott, H. (2011). Journal list fetishism and the perversion of scholarship: reactivity and the ABS list. Organization, 18, pp. 429-442.

Wilson, J., Arshed, N., Shaw, E. and Pret, T. (2017). Expanding the domain of festival research: a review and research agenda. International Journal of Management Reviews, 17, pp.195-213.

Zukin, S. and DiMaggio, P. (1990). Introduction. In Zukin, S. and DiMaggio, P. (eds), Structures of Capital: The Social Organization of the Economy, Cambridge: Cambridge University Press, pp. 1-36. 